and the need for stochastic models: he argues that mechanistic models, though attracting most of the effort (as they still do) have so many degrees of freedom as to be unreliable tools for experimentation and for sensitivity tests, let alone for climate forecasts.

The section on exploration technology has three papers: R. B. Abel on satellite oceanography is inevitably dated, as are G. Kullenberg's reflections on ocean observations. It is a pity that his reference to the great salinity anomaly in the North Atlantic is to that of 1910-1914 and not to the recently described and better documented anomaly of the $1970 \mathrm{~s}$. The section entitled 'The Exploration of Inner Space' is a detailed historical account of the development (to 1985) of submarines, bathyscaphes and submersibles presented by D. Walsh, who was an early US Navy commander of the bathyscaphe Trieste.

The lead paper on ocean resources is by E. D. Stehling, who concentrates on fisheries. Possible uses of ocean space is the concern of E. D. Goldberg in a welldocumented paper, updated with recent references, that makes a case for the deep-sea disposal of various kinds of waste. He concludes that "the great expanse of open space may be underutilized with respect to the waste disposal needs of a growing world population", a

\section{New releases}

\section{Mark Williamson}

Introduction of Genetically Modified Organisms into the Environment, SCOPE 44. Edited by H. A. Mooney and G. Bernardi. Wiley: 1990. Pp. 201. £45; $\$ 110$. Assessing Ecological Risks of Biotechnology. Edited by L. R. Ginzburg. Butterworth-Heinemann: 1991. Pp. 379. $\$ 79.95, £ 56$.

Do new genetic techniques pose a threat to the environment? There is now a lot of money going into the development of genetically novel microbes, plants and animals for agricultural and other uses. So far there have been only a few hundred, mostly small-scale, field trials. These have usually, but by no means always, involved rather trivial genetic changes. But largerscale releases of ecologically interesting novelties can be expected. How can the risks be assessed?

This topic involves an interaction between molecular genetics, ecology, agriculture, public policy and public concern. There is disagreement about its scope. In the European Communities (EC) the new Directive covers a wide range of genetic novelty, including some types of cell fusion; in the United States the official range of novelty is narrower. Only four of the EC member states had viewpoint immediately contradicted by G. Stanhill who states that "to date the only global modification that man appears to have achieved is the inadvertent, shameful and near ubiquitous pollution caused by the estimated 6-million tons of solid and liquid waste now disposed of in the ocean". He goes on to describe four projects that would involve modification of the water balance of the Mediterranean Sea. Finally, the section on ocean commerce avoids any consideration of merchant shipping, although it does deal with tunnels off Japan (Y. Mochida), with ocean voyagers in prehistory (W. Bascom) and with attempts to stop the sinking of Venice (R. Frassetto).

The Ocean in Human Affairs is a collection of papers, not a book, and the few tasty dishes do not make a meal. This one ends with an over-egged pudding by the veteran Athelstan Spilhaus, extolling the unity of the ocean and the virtues of those who go to sea. He provides a new map showing the whole ocean and all the continents uncut by the edge of the map and asks "Is it art? Is it science? Or is it both, unified, to give us understanding and joy?" It seems to me that the editor has a lot to answer for.

H. Charnock is in the Department of Oceanography, The University, Southampton. SOg $5 \mathrm{NH}$, UK.

satisfactory regulatory and risk assessment procedures in place before the Directive was issued. In the United States, the Federal approach is widely seen as confused, fragmented and complacent, and so some individual states have set up their own procedures. There is no doubt that it is difficult to be well informed about what is going on, and difficult too to understand all the implications of some of the proposals.

These two symposia show something of the range of science involved, and the range of options. SCOPE 44 is the result of collaboration of two committees of the International Council of Scientific Unions (ICSU) - the Committee on Genetic Experimentation (COGENE) and SCOPE itself (the Scientific Committee on Problems of the Environment). It is a thoroughly international symposium, with 15 papers by 29 contributors from 10 countries. Surprisingly, we are not told that the symposium took place in 1987 . No discussion is reported, though there is a list of six extra participants in the discussions, and one consequence of the discussions, a joint SCOPE/COGENE statement that takes three pages. It is a pity that that statement was upstaged by the booklet Recombinant DNA Safety Considerations (published by the Organization for Economic Co-operation and Development, 1986), which, surprisingly in view of its influence, is not mentioned in either of these symposia.
The SCOPE/COGENE statement mostly accords with present practice, particularly in the emphasis on the product rather than the process by which it is formed, and in case-by-case review. But there are two surprises. The first is that "small-scale field testing involves different considerations than does large-scale" which appears to negate the idea that small-scale trials are necessary to collect the data to allow us to proceed safely with large-scale ones, with the consequence that small-scale trials will be more closely regulated than large ones. The other surprise is the statement that "the risks of making a specific introduction must be balanced against the perceived benefits and the risks of not making the introduction". Briefly I can only say that, in general, that does not happen in practice, for good reasons, amongst which are that the two sorts of risks often impinge on different constituencies.

Assessing Ecological Risks of Biotechnology edited by Ginzburg is not the report of a meeting. It makes a valiant attempt to look at risk assessment in the light of what has happened with biological invasions and biological control, of what is known of the ecology and genetics of microbes, of what can be predicted from models, and of the US regulatory procedures. Its main weaknesses are its neglect of what is happening outside the United States and inside plants. The majority of proposals at the moment are of plants. The editor justifies their neglect by saying these novel plants involve microbes. But the microbe comes in at an intermediate stage; most of the risk assessment must concentrate on the plant, its ecological characteristics and its relatives. On the other point, the only one of 17 chapters by a non-American is an out-ofdate account of the European regulatory system.

This whole topic brings together the rapidly advancing subject of molecular genetics, where there is certainly still much to learn, and the much less advanced and rather confused subject of population and community ecology, in an arena dominated by the economic forces of agribusiness. In such a situation it is impossible for a published symposium to be fully up to date. Critical assessments of the relevant science, as by Frank Fenner on the epidemiology of animal viruses in the SCOPE volume, or of actual case histories, as by H. R. Akcakaya and L. R. Ginzburg in the other one, are of lasting value. As it is more consistently in this style, as well as more up to date, the latter is the better value. But most people in this field, whether researchers, entrepreneurs or regulators, will want access to both.

Mark Williamson is in the Department of Biology, University of York, York Y01 5DD, UK.

NATURE · VOL 349 · 14 FEBRUARY 1991 